\title{
Estimasi Produk Degradasi Ekstrak Kasar Pigmen Alga Merah Kappaphycus alvarezil (Doty) Doty Varian Merah, Coklat, dan Hijau: Telaah Perbedaan Spektrum Serapan
}

\section{Helly de Fretes ${ }^{1 *}$, AB. Susanto ${ }^{2}$, Budhi Prasetyo ${ }^{1}$, Heriyanto ${ }^{3}$, Tatas H. P. Brotosudarmo ${ }^{3}$ dan Leenawaty Limantara ${ }^{3}$}

\author{
${ }_{1}^{1}$ Magister Biologi, Universitas Kristen Satya Wacana, Salatiga, Jawa Tengah 50711 \\ e-mail: jlay_43120@yahoo.com \\ 2Jurusan IImu Kelautan, FPIK, Universitas Diponegoro, Tembalang, Semarang 50275, e-mail: \\ abesusanto08@yahoo.com \\ ${ }_{3}^{3}$ Ma Chung Research Center for Photosynthetic Pigments, Universitas Ma Chung, Malang 65151, e-mail: \\ leenawaty.limantara@machung.ac.id
}

\begin{abstract}
Abstrak
Penelitian ini bertujuan untuk mengestimasi produk degradasi pigmen ekstrak kasar alga merah Kappaphycus alvarezii (Doty) Doty varian merah, coklat dan hijau yang terbentuk selama perlakuan iradiasi dan pemanasan, melalui perbedaan spektrum serapannya. Ketiga varian diekstraksi menggunakan 100\% metanol. Uji fotostabilitas ekstrak pigmen dilakukan dengan iradiasi menggunakan lampu Volpi intralux 4100 pada intensitas cahaya 39300 lux, 56700 lux dan 76400 lux. Lama waktu penyinaran 0, 5, 10, 15, dan 20 menit. Sedangkan uji termostabilitas dilakukan pada suhu 25 dan $90^{\circ} \mathrm{C}$ selama 0, 3, 624 , dan 48 jam. Pola spektra diukur pada panjang gelombang 300-800 nm sebelum dan sesudah perlakuan dengan spektrofotometer UV-Tampak Shimadzu 1700. Data dianalisis dengan SPINA Versi 3, untuk memperoleh intensitas maksimum dan perbedaan spektra serapan. Hasil penelitian menunjukkan bahwa produk degradasi pigmen ekstrak kasar alga merah K. alvarezii dapat diidentifikasi melalui spektrum serapan dan hasil perbedaan spektra serapan. Isomer cis karotenoid, karotenoid tidak berwarna, dan feofitin a diestimasi sebagai produk degradasi yang terbentuk selama perlakuan iradiasi dengan intensitas cahaya 76400 lux dan perlakuan pemanasan pada suhu $90^{\circ} \mathrm{C}$ selama 48 jam. Penurunan intensitas warna larutan pigmen juga mengindikasikan terbentuknya produk degradasi selama perlakuan.
\end{abstract}

Kata kunci: Kappaphycus alvarezii, perbedaan spektrum serapan, produk degradasi

\section{Abstract}

Estimation on Degradation Products of Crude Pigment Extracts from Red, Brown, and Green Varieties of Red Alga Kappaphycus alvarezii (Doty) Doty: Difference Absorption Spectra Studies

The aims of this study were to estimate the degradation products of crude pigment extracts from red, brown, and green varieties of red alga Kappaphycus alverezii (Doty) Doty that formed during irradiation and heating treatment from their difference absorption spectra. All three variants were extracted using $100 \%$ methanol. The photostability assay of crude pigment extracts was conducted by irradiating the crude pigment extracts with a day light lamp (Volpi, Intralux 4100) at 39300 lux, 56700 lux and 76400 lux light intensity during 0, 5, 10, 15, and 20 minutes treatment, whereas the thermostability assay was performed at 25 and $90{ }^{\circ} \mathrm{C}$ for $0,3,624$, and 48 hours. The absorption spectra of the crude pigment extract before and after each treatment were monitored successively at 300-800 nm using MultiSpec 1501 UV-VIS spectrophotometer. Data were analyzed with spina Version 3, to obtain maximum intensity and the difference absorption spectra. The results showed that the degradation products of crude pigment extracts from red alga $\mathrm{K}$. alvarezii could be identified by absorption spectra and difference absorption spectra. Cis isomers carotenoids, colorless carotenoids, and feofitin-a were estimated as degradation product formed during the irradiation treatment with 76400 lux of light intensity and heating treatment at a temperature of $90{ }^{\circ} \mathrm{C}$ for 48 hours. Decrease in the intensity of the color of pigment solution also indicates the formation of degradation products during treatment.

Key words: Kappaphycus alvarezii, difference absorption spectra, degradation products

\section{Pendahuluan}

Luas perairan laut Indonesia serta keragaman dalam jumlah maupun jenis algae (atau yang secara komersil dikenal dengan sebutan rumput laut) merupakan cerminan dari potensi alga Indonesia. Di lautan, algae diwakili oleh 3 divisi terbesar yaitu Chlorophyta, Phaeophyta dan Rhodophyta yang 
merupakan algae makro. Salah satu anggota divisi Rhodophyta terkenal dan telah banyak dibudidayakan untuk kepentingan perekonomian adalah jenis Kappaphycus alvarezii (Doty) Doty. Jenis ini dikenal sebagai penghasil karaginan (karagenofit). Selain mineral, vitamin, polisakarida dan serat, kandungan nutrisi yang penting pada algae merah adalah pigmen. Pigmen dominan yang terdapat pada algae merah adalah klorofil $a$, klorofil $d$, zeaxantin, likopen kriptoxantin, $\alpha$-karoten, $\beta$-karoten, lutein, dan pikobilin (Luning, 1990).

Salah satu ciri khas pigmen adalah ketidakstabilannya terhadap cahaya, $\mathrm{pH}$, suhu, oksigen dan pelarut alkohol. Intensitas cahaya yang tinggi dan waktu iradiasi cahaya yang lama dapat menyebabkan degradasi klorofil (Gross, 1991). Klorofil yang terdegradasi akan membentuk produk degradasi seperti feofitin dan feoforbid (Limantara, 2005), sementara karotenoid akan membentuk cis-isomer sebagai produk degradasi akibat proses stereoisomerisasi karena faktor suhu, cahaya, asam, perbedaan struktur, dll (Britton et al., 1995; Parker, 1996; Bohm et al., 2002).

Algae memiliki kisaran toleransi dan respon terhadap intensitas cahaya. Algae dapat memutih (bleaching) jika berada dibawah intensitas cahaya yang tinggi, sementara pertumbuhan algae menjadi terhambat jika tumbuh pada daerah denganintensitas cahaya rendah. Ekstrak kasar pigmen $K$. alvarezii juga menunjukkan respon terhadap perlakuan yang diujikan dalam penelitian ini. Berbagai metode pengolahan, seperti pemanasan dan pengeringan juga menyebabkan degradasi sehingga membentuk produk degradasi pigmen, yang dapat dipastikan keberadaanya melalui serapan positif yang muncul sebagai hasil proses subtraksi pola spektra untuk tiap seri iradiasi maupun suhu pemanasan. Selain itu, warna larutan ekstrak kasar pigmen dapat juga digunakan sebagai parameter untuk menganalisa pembentukan produk degradasi. Produk degradasi yang terbentuk selama perlakuan, dapat diidentifikasi secara sederhana tanpa menggunakan metode Kromatografi Cair Kinerja Tinggi (KCKT), hanya berdasarkan puncak-puncak serapan spektrum absorpsi yang muncul pada panjang gelombang antara 300-700 nm.

Penelitian ini bertujuan untuk mengestimasi produk degradasi pigmen ekstrak kasar alga merah $\mathrm{K}$. alvarezii varian merah, coklat dan hijau yang terbentuk selama perlakuan iradiasi dan pemanasan, melalui perbedaan spektrum serapannya.

\section{Materi dan Metode}

Penelitian ini dilakukan di Ma Chung Research
Centre for Photosynthetic Pigments (MRCPP), Universitas Ma-Chung, Malang pada bulan AgustusOktober 2011. Materi yang digunakan adalah alga merah $K$. alvarezii varian merah, coklat dan hijau (Gambar 1), yang diperoleh dari lahan budidaya Desa Wael, Kabupaten Seram Bagian Barat, Maluku. Bahan kimia yang digunakan adalah aseton, metanol, dietileter, petroleum eter, $\mathrm{CaCO}_{3}$, asam askorbat, akuades dan gas argon.

\section{Ekstraksi pigmen}

Sebanyak 50 gram sampel dihaluskan menggunakan blender, dan ditambahkan $60 \mathrm{ml}$ pelarut metanol 100\%, $1 \mathrm{gr} \mathrm{CaCO}_{3}$ sebagai penetral, dan asam askorbat sebagai antioksidan. Sampel diekstraksi sebanyak 3 kali menggunakan stirer dengan kecepatan $750 \mathrm{rpm}$ selama 10 menit hingga warna pelet menjadi pucat. Selanjutnya ekstrak difiltrasi menggunakan kertas saring dan dipartisi dengan pelarut dietil eter dan petroleum eter. Larutan ekstrak kasar dievaporasi dan dikeringkan dengan gas argon (Britton et al., 1995).

\section{Iradiasi ekstrak kasar pigmen K. alvarezii dan analisis} spektra UV-tampak

Uji fotostabilitas ekstrak kasar pigmen $K$. alvarezii varian merah, coklat, dan hijau dilakukan dengan melarutkan ekstrak kasar pigmen dalam aseton, dan diatur absorbansi larutan mendekati 1. Larutan pigmen sebanyak $3,5 \mathrm{ml}$ dimasukan dalam kuvet dan diiradiasi menggunakan lampu Volpi intralux dengan intensitas cahaya sebesar 39300, 56700 dan 76400 lux. Lama waktu penyinaran $0,5,10,15$, dan 20 menit.

\section{Termostabilitas ekstrak kasar pigmen K. alvarezii}

Sebanyak $10 \mathrm{ml}$ larutan ekstrak kasar pigmen masing-masing varian dimasukan dalam tabung reaksi berulir dan dipanaskan menggunakan waterbath pada suhu $90^{\circ} \mathrm{C}$ selama $0,3,6,24$, dan 48 jam.

\section{Pola spektra ekstrak kasar pigmen K. alvarezii}

Pola spektra diukur pada panjang gelombang 300-800 nm sebelum dan sesudah perlakuan menggunakan spektrofotometer UV-Tampak Shimadzu 1700.

\section{Analisis data}

Intensitas maksimum dan perbedaan spektra serapan dilakukan pada perangkat lunak SPINA Versi 3 (dibuat oleh Y. Katsumoto, Hiroshima University) dan diplotkan dengan bantuan perangkat lunak Plot32 (dibuat oleh A. Ikehata, KGU Jepang). 


\section{Hasil dan Pembahasan}

Pola spektra dan perbedaan spektra serapan ekstrak kasar pigmen K. alvarezii

Komposisi pigmen yang dikandung oleh ketiga varian alga merah $\mathrm{K}$. alvarezii dapat diestimasi dengan menganalisa pola spektra ekstrak kasar pigmen $\mathrm{K}$. alvarezii yang tampak pada Gambar 2a. Berdasarkan hasil tersebut, tampak bahwa ketiga varian yaitu varian merah, coklat, dan hijau memiliki komposisi pigmen yang hampir sama. Namun kemungkinan ketiga varian tersebut berbeda pada kandungan masing-masing pigmen yang dapat dilihat dari adanya perbedaan nilai absorbansi masing-masing varian.

Puncak-puncak serapan yang muncul merupakan puncak serapan pigmen yang terkandung pada alga merah K. alvarezii. Berdasarkan nilai serapan maksimum, tampak keberadaan klorofil a pada K. alvarezii memiliki serapan maksimum pita Qy pada $660-662 \mathrm{~nm}$. Serapan maksimum pada $668 \mathrm{~nm}$, merupakan serapan yang dimiliki oleh feofitin a. Sementara untuk pigmen karotenoid yang dikandung oleh $\mathrm{K}$. alvarezii, diduga merupakan $\beta$-karoten dengan serapan maksimum pada 478,5 nm (Indrawaty et al., 2010).

Kandungan pigmen bervariasi antar tiap varian. Perbedaan spektra serapan ekstrak kasar pigmen K. alvarezii varian merah, coklat, dan hijau dengan varian merah sebagai spektrum referensi, menunjukkan bahwa varian coklat memiliki kandungan pigmen yang paling tinggi dibandingkan dengan varian merah dan hijau (Gambar 2b). Luas puncak dengan serapan maksimum pada $457 \mathrm{~nm}$, mengindikasikan kandungan karotenoid total tertinggi dimiliki oleh varian coklat. Hal ini sesuai dengan hasil penelitian de Fretes, et al. (2011), dimana varian coklat menunjukkan luas area total karotenoid tertinggi atau sebesar 1352,18/gram berat kering. $\mathrm{K}$. alvarezii varian hijau merupakan varian dengan jumlah kandungan pigmen terendah berdasarkan luas area total karotenoid $(1174,42 /$ gram berat kering) dibandingkan dengan varian merah (1350,69/gram berat kering) dan coklat.

\section{Perbedaan spektra serapan ekstrak kasar pigmen $\mathrm{K}$. alvarezii setelah diiradiasi}

Puncak serapan maksimum mengalami pergeseran selama perlakuan iradiasi dengan intensitas cahaya 76400 lux selama 20 menit (Gambar 3a). Pola serapan ekstrak kasar pigmen karotenoid $K$. alvarezii sebelum iradiasi menunjukkan puncak serapan maksimum pada panjang gelombang $433 \mathrm{~nm}$ untuk varian merah, dan $431 \mathrm{~nm}$ untuk varian coklat dan hijau. Setelah diradiasi selama 20 menit, terjadi pergeseran serapan maksimum panjang gelombang secara berturut-turut untuk varian merah, coklat, dan hijau, menjadi $431 \mathrm{~nm}, 430 \mathrm{~nm}$, dan 430 $\mathrm{nm}$. Pergeseran puncak serapan maksimum menandakan bahwa intensitas cahaya yang digunakan dalam perlakuan iradiasi ini cukup untuk dapat menimbulkan kerusakan yang signifikan terhadap ekstrak kasar pigmen dan membentuk produk degradasi pigmen.

Produk degradasi pigmen ekstrak kasar $K$. alvarezii varian merah, coklat, dan hijau, selama perlakuan iradiasi dapat diidentifikasi secara kasar berdasarkan hasil perbedaan spektra serapan pigmen ekstrak kasar pada 0, 5, 10, 15, dan 20 menit iradiasi (Gambar 3b). Komposisi pigmen yang terkandung pada larutan ekstrak kasar $K$. alvarezii varian merah, coklat, dan hijau yang teridentifikasi pada penelitian sebelumnya berdasarkan metode KCKT adalah violaxantin, $\alpha$-Kriptoxantin, anteraxantin, zeaxantin, klorofil a, feofitin $a$, dan $\beta$-karoten.

Serapan positif yang terdapat pada perbedaan spektra berasal dari spektra serapan produk degradasi pigmen. Produk degradasi yang terbentuk selama 20 menit perlakuan iradiasi memiliki puncak serapan pada 354, 355, 358,393, 395,549, 552, 697, 695, dan $698 \mathrm{~nm}$. Produk degradasi dengan serapan maksimum sekitar 350-390 nm merupakan daerah serapan cis-karotenoid yang terbentuk selama perlakuan. Sebagaimana yang dijelaskan oleh Britton (1995) bahwa spektrum UV cis-karotenoid ditandai dengan munculnya puncak pada $\lambda_{\max } 330-350 \mathrm{~nm}$, dengan intensitas terbesar ketika ikatan rangkap terletak dekat atau di tengah kromofor.

Perbedaan spektra serapan ekstrak kasar pigmen $\mathrm{K}$. alvarezii setelah pemanasan

Pada perlakuan $90^{\circ} \mathrm{C}$ pigmen ekstrak kasar selama 48 jam juga terjadi pergeseran puncak serapan maksimum. Puncak serapan maksimum ketiga varian bergeser ke arah hipsokromik sebesar $1,5 \mathrm{~nm}$ setelah pemanasan selama 48 jam. Pergeseran puncak serapan maksimum ini mengindikasikan terjadinya isomerisasi cis-trans karotenoid (Schieber \& Carle, 2005).

Produk degradasi yang terbentuk selama perlakuan pemanasan $90^{\circ} \mathrm{C}$ selama 48 jam terhadap pigmen ekstrak kasar $K$. alvarezii varian merah, coklat, dan hijau, dapat diketahui dan diidentifikasi secara kasar dari perbedaan spektra serapannya. Perbedaan spektra serapan selama perlakuan pemanasan ditunjukan pada Gambar 4.

Berdasarkan perbedaan spektrum serapan pigmen ekstrak kasar K. alvarezii varian merah, coklat, dan hijau, terdapat serapan positif yang muncul pada panjang gelombang 342, 343, 345, 546, 547, 553, 


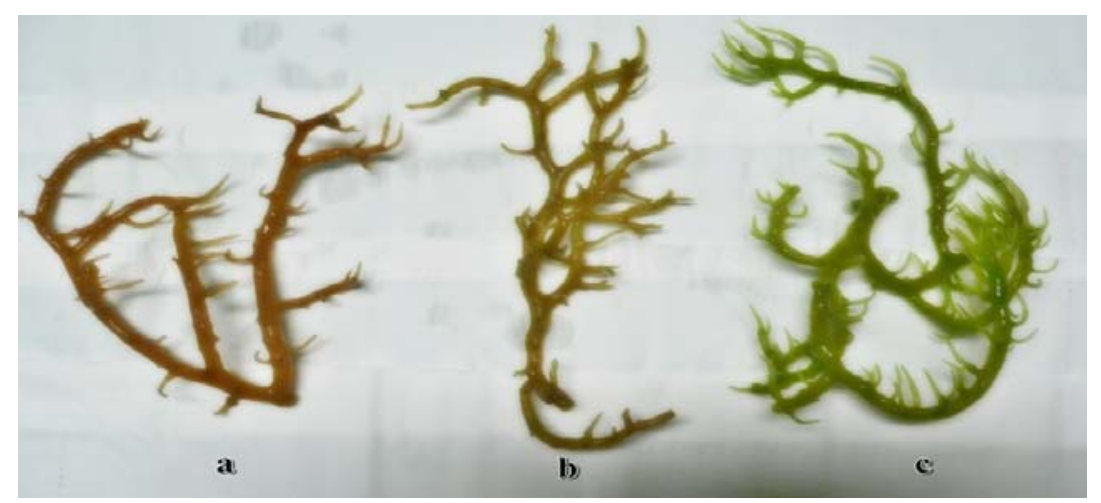

Gambar 1. Sampel alga merah K. alvarezii varian merah (a), coklat (b), dan hijau (c).

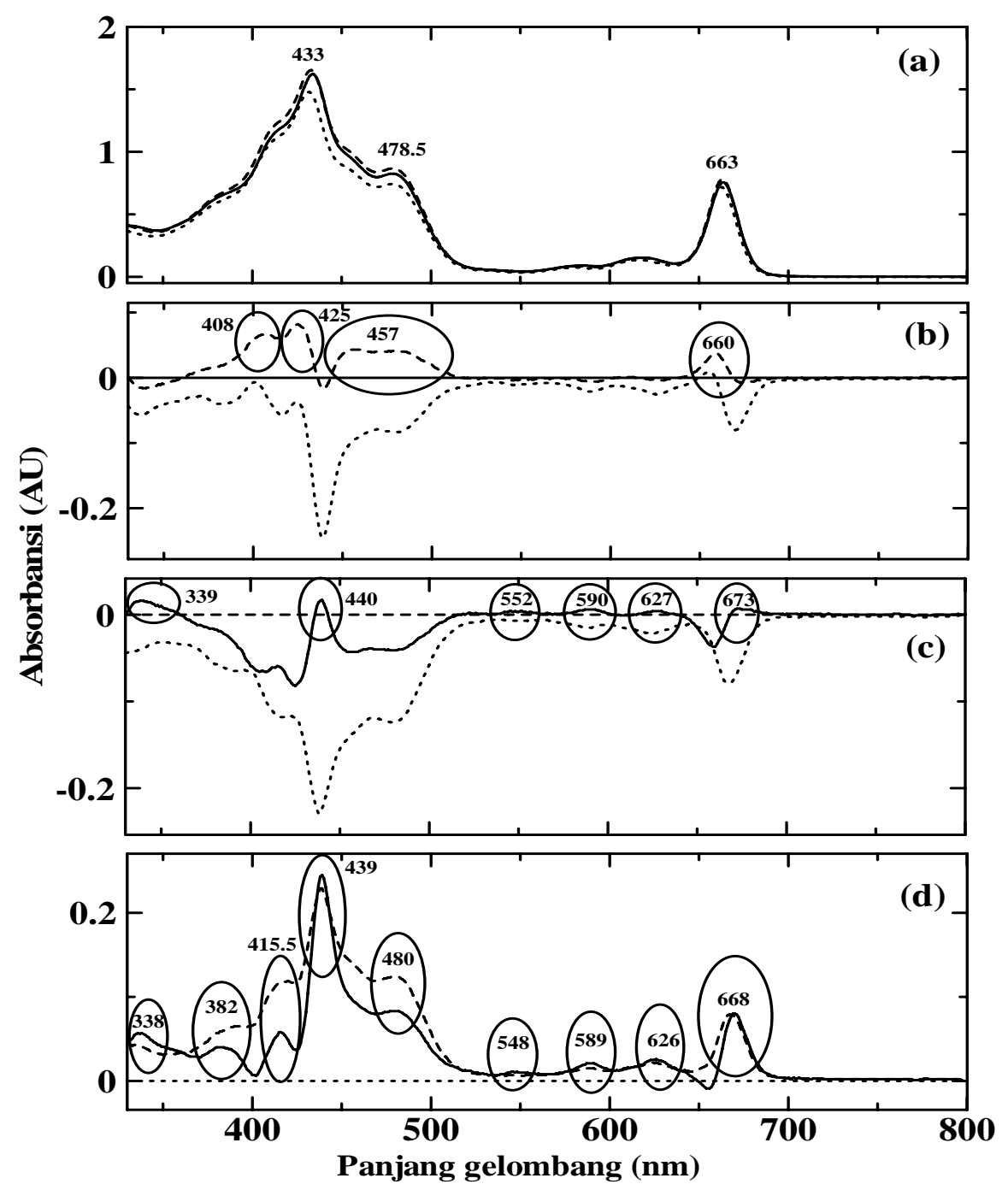

Gambar 2. Pola spektra ekstrak kasar pigmen K. alvarezii varian merah (--------), coklat (- - - - - - -) dan hijau (.........) (a) dan perbedaan spektra serapan hasil subtraksi dengan spektrum referensi varian merah (b), spektrum referensi varian coklat (c), dan spektrum referensi varian hijau (d). 


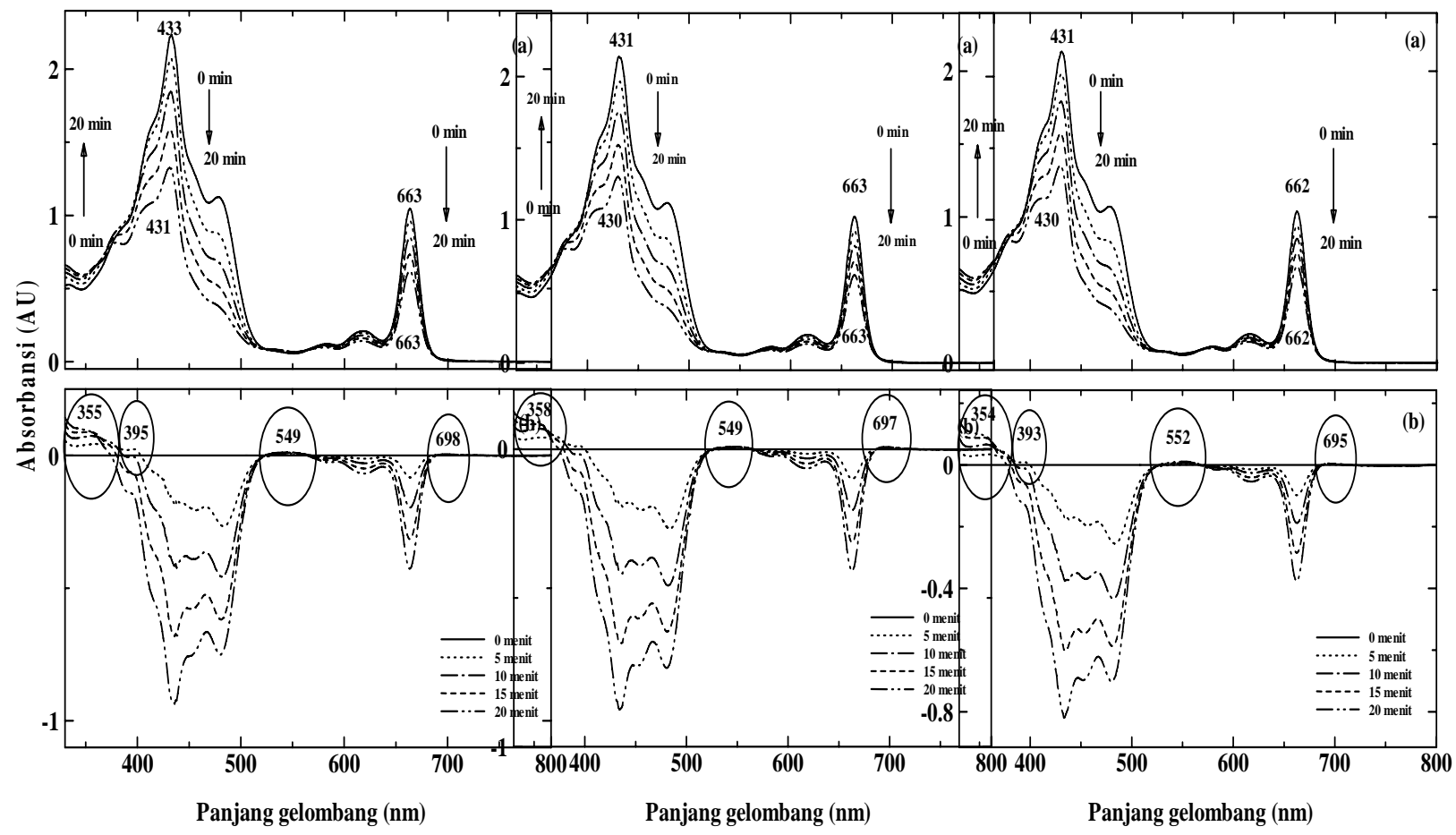

Gambar 3. Pola spektra (a) dan hasil perbedaan spektra serapan (b) antara ekstrak kasar pigmen K. alvarezii varian merah (A), coklat (B) dan hijau (C) setelah diiradiasi dengan intensitas cahaya 76.400 lux selama 0, 5, 10, 15 dan 20 menit dengan spektrum ekstrak kasar 0 menit sebagai spektrum referensi.

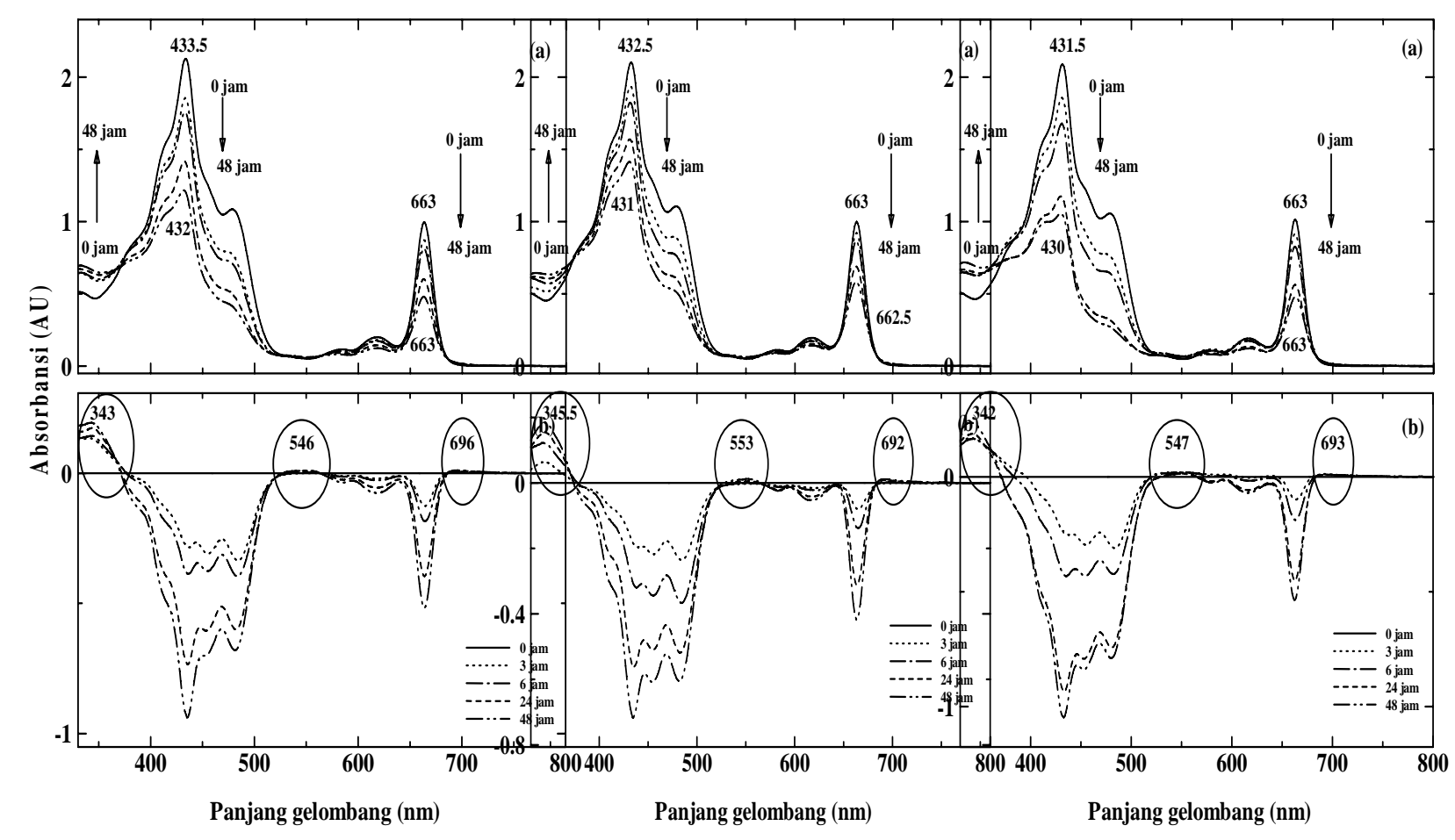

Gambar 4. Pola spektra dan hasil perbedaan spektra serapan antara ekstrak kasar pigmen $K$. alvarezii varian merah (A), coklat (B) dan hijau (C) setelah pemanasan pada suhu $90^{\circ} \mathrm{C}$ selama $0,3,6,24$ dan 48 jam dengan spektrum ekstrak kasar 0 jam sebagai spektrum referensi. 
(A)

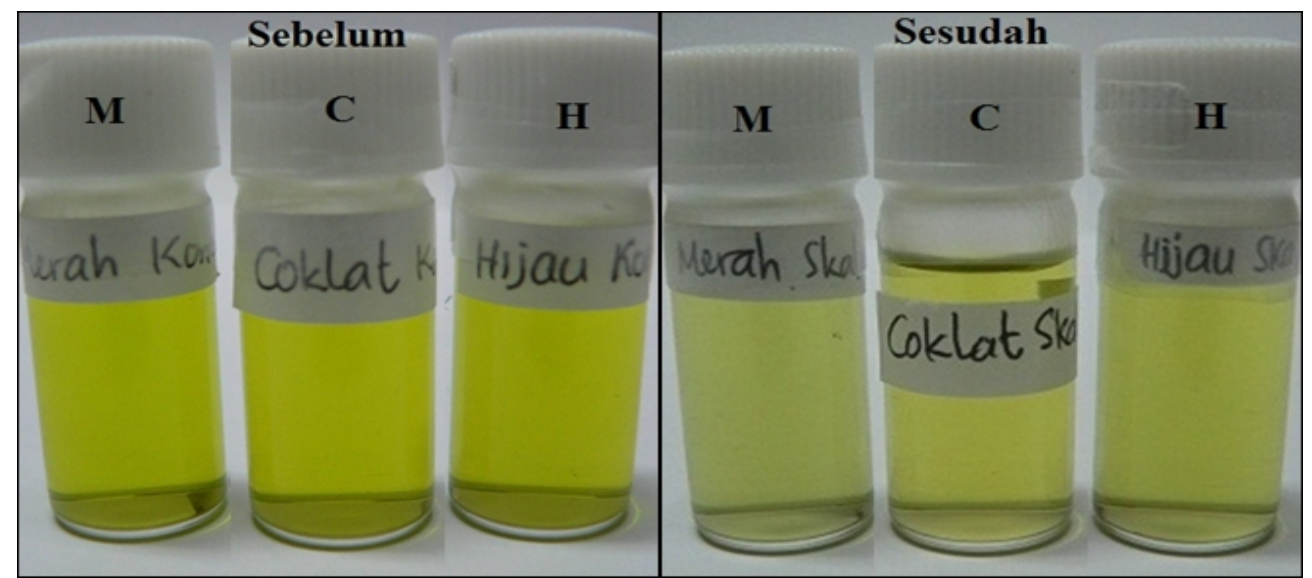

(B)

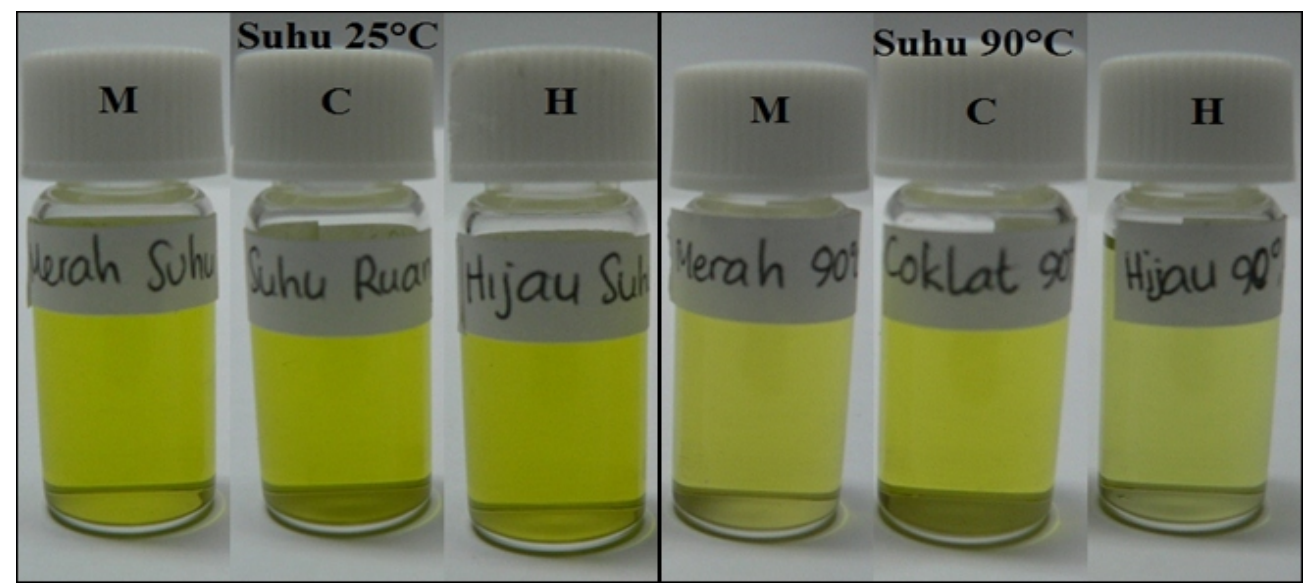

Gambar 3. Larutan pigmen ekstrak kasar $K$. alvarezii varian merah, coklat dan hijau, sebelum dan sesudah iradiasi dengan intensitas cahaya 76400 lux selama 20 menit (A), setelah 48 jam perlakuan pemanasan pada suhu ruang $25^{\circ} \mathrm{C}$ dan suhu $90^{\circ} \mathrm{C}(\mathrm{B})$.

692, 693, dan 696. Hal ini mengindikasikan terbentuknya isomer cis-karotenoid dengan serapan maksimum pada $342,343,345 \mathrm{~nm}$, selama perlakuan pemanasan 48 jam. Produk degradasi karotenoid yang lain berupa karotenoid tidak berwarna dengan ikatan rangkap terkonjugasi kurang dari 7 serta molekul kecil dan tidak berwarna.

\section{Warna larutan pigmen}

Dalam aplikasinya sebagai pewarna makanan, karotenoid misalnya, cenderung mengalami isomerisasi dan oksidasi, yang mengakibatkan hilangnya warna dan aktivitas biologis (RodriquesAmaya, 1999). Perubahan selama fotodegradasi meliputi perubahan komposisi, perubahan warna, pemutusan ikatan, dan pengaturan kembali atomatom dalam suatu molekul (Willes and Carrison, 1987 dalam Suparmi et al., 2007; Lagowski, 1997 dalam Suparmi et al., 2007).
Selain melalui spektrum serapan, estimasi pembentukan produk degradasi pigmen dapat pula dilakukan dengan melakukan pengamatan terhadap warna larutan pigmen. Larutan pigmen ekstrak kasar selama perlakuan iradiasi dan pemanasan ditunjukan oleh Gambar 5. Secara visual terlihat adanya perubahan warna larutan pigmen sebelum (kontrol) dan sesudah perlakuan. Larutan pigmen kontrol tampak berwarna kuning, namun larutan pigmen ektrak kasar setelah perlakuan iradiasi pada intensitas cahaya 76400 lux selama 20 menit, tampak memucat. Hal yang sama juga terjadi pada perlakuan pemanasan suhu $90^{\circ} \mathrm{C}$ selama $48 \mathrm{jam}$, dibandingkan dengan warna larutan pigmen pada perlakuan suhu ruang $25^{\circ} \mathrm{C}$.

Hasil ini menunjukkan bahwa telah terjadi degradasi pigmen baik klorofil maupun karotenoid. Hal ini sesuai dengan pernyataan Sajilata \& Singhal (2006) dan Gross (1991) yang menjelaskan bahwa perubahan 
warna pada pigmen menunjukkan terjadinya degradasi akibat terpapar pada cahaya dengan intensitas tinggi dan dalam waktu yang cukup lama.

Klorofil sangat mudah terdegradasi oleh cahaya, $\mathrm{pH}$, suhu, oksigen dan alkohol yang berlebihan. Intensitas cahaya yang tinggi dan waktu iradiasi cahaya yang lama dapat menyebabkan degradasi klorofil (Gross, 1991). Degradasi oksidatif karotenoid karena berbagai metode pengolahan dapat menyebabkan isomerisasi cis-trans dan pembentukan epoksida karotenoid (Khoo et al., 2011). Penelitian sebelumnya telah menunjukkan bahwa cis-isomer dari karotenoid dapat diidentifikasi berdasarkan karakteristik spektrum penyerapan, rasio pita $\mathrm{Q}$, dan intensitas relatif dari puncak cis (Khoo et al., 2011). Di sisi lain, terjadi penurunan hipokromik di panjang gelombang maksimum sehingga terjadi pembentukan isomerisasi cis-trans karotenoid dan menyebabkan penurunan intensitas warna (Schieber \& Carle, 2005).

\section{Kesimpulan}

Hasil substraksi spektrum serapan ekstrak kasar pigmen alga merah $K$. alvarezii menunjukkan perbedaan kandungan pigmen pada masing-masing varian, dengan komposisi pigmen yang relatif sama baik pada varian merah, coklat, maupun hijau. Produk degradasi pigmen ekstrak kasar alga merah $K$. alvarezii dapat diketahui melalui spektrum serapan dan hasil perbedaan spektra serapan. Isomer cis karotenoid, karotenoid tidak berwarna, dan feofitin a diestimasi sebagai produk degradasi yang terbentuk selama perlakuan iradiasi dengan intensitas cahaya 76400 lux dan perlakuan pemanasan pada suhu $90^{\circ} \mathrm{C}$ selama $48 \mathrm{jam}$. Penurunan intensitas warna larutan pigmen juga mengindikasikan terbentuknya produk degradasi selama perlakuan.

\section{Ucapan Terima Kasih}

Helly de Fretes mengucapkan terima kasih kepada Departemen Pendidikan Nasional terutama untuk program Beasiswa Unggulan yang telah diselenggarakan di Universitas Kristen Satya Wacana. Leenawaty Limantara mengucapkan terima kasih atas hibah kompetensi dari Dikti tahun 2010 dengan No.: 424/SP2H/PP/DP2M/VI/2010 dan tahun 2011 dengan No. 388/SP2H/PL/Dit.Litabmas/IV/2011 serta hibah penelitian desentralisasi skim unggulan PT No. 2500/E5.2/PL/2011 dan 0119/E5.2/PL/ 2012 tahun 2012.

\section{Daftar Pustaka}

Bohm, V. Puspitasari-Nienaber, N.L., Ferruzzi, M.G., \& Schwartz, S.J. 2002. Trolox equivalent antioxidant capacity of different geometrical isomers of $\alpha$-carotene, $\beta$-carotene, lycopene, and zeaxanthin. J. Agric. Food Chem., 50: 221-226.

Britton, G., S. Liaaen-Jensen, \& H. Pfander. 1995. Carotenoids Volume IA : Isolation and Analysis. Birkhauser Verlag, Basel Boston, Berlin, 8184pp.

Britton, G. 1995. UV/Visible Spectroscopy. In: Britton, G., Liaaen-Jensen, S., \& Pfander, H. (Eds.). Carotenoids Volume 1B: Spectroscopy. Eds.; Birkhauser Verlag, Basel Boston, Berlin, 5761pp.

de Fretes, H., A.B. Susanto, L. Limantara, B. Prasetyo, Heriyanto, \& T.H.P. Brotosudarmo. 2011. Composition and content of pigment, photostability and thermostability studies of crude pigment extracts from red, brown, and green varieties of red algae Kappaphycus alvarezii (Doty) Doty. Seminar ICONS, Universitas Ma Chung, Malang.

Gross, J., 1991. Pigment in Vegetables (Chlorophylls and Carotenoids). Van Norstran Reinhold. New York. $775 p$.

Indrawati, R., Heriyanto, L. Limantara, \& A. Susanto. 2010. Study of pigments distribution in the stem, leaf and vesicle of Sargassum filipendula C. Agardh, Sargassum polycystum C. Agardh and other Sargassum spp. from Madura waters by High Performance Liquid Chromatography Proc. NP-SEA 2010. Malang. MRCPP, Pp. 275-280.

Khoo, H. E., K.N. Prasad, K.W. Kong, Y. Jiang, \& A. Ismail. 2011. Carotenoids and their isomers: Color pigments in fruits and vegetables. Molecules, 16: 1710-1738.

Limantara, L. 2005. Photostability of bacteriochlorophyll derivatives relevant photodynamic therapy of cancer: Study in organic solvent. Seminar Nasional MIPS 2005. FMIPAUniversitas Indonesia.

Lüning, K. 1990. Seaweeds - Their Environment, Biogeography, and Ecophysiology. A WileyInterscience Publication.

Parker, R. 1996. Absorption, metabolism, and transport of carotenoids. FASEB Journal, 10: 542-551.

Rodriguez-Amaya, D. B. 1999. Changes in carotenoids during processing and storage of food. Archivos Latinoamericanos de Nutricion, 49(1- 
8):3 8-47.

Sajilata \& Singhal, 2006. Isolation and Stabilitation of Natural Pigments for Food Application. Stewart Postharvest Review, 5-11.

Schieber, A., \& R. Carle. 2005. Occurrence of carotenoid cis-isomers in food: Technological, analytical, and nutritional implications. Trends Food Sci. Technol., 16: 416-422.

Suparmi, B. Prasetyo, \& L. Limantara, 2007. Fotodegradasi pigmen bixin dari biji kesumba (Bixa orellana) : Potensi sebagai Pewarna Alami Makanan. Seminar Nasional Pigmen "Back to Nature”. Salatiga. Magister Biologi UKSW.. 